УДК 821.163.41.09 Андрић, И. https://doi.org/10.18485/msc50.2019.1.ch41

Габријела Шуберт

\title{
СЛИКА ЦРЬАНСКОГ О НЕМЦИМА У ПУТОПИСУ ИРИС БЕРЛИНА И У ЊЕГОВИМ ПОЛИТИЧКИМ КОМЕНТАРИМА
}

\begin{abstract}
Истакнути српски писац Милош Црњански је добро познавао Немачку - из лектире немачке књижевности као и из личних посета Немачкој. Први пут је боравио у Немачкој 1928. и 1929. године, а други пут од децембра 1935. до марта 1938. године.
\end{abstract}

Када је Црњански у јуну 1927. године ступио у дипломатску службу, како пише „без нарочите жеље и без неког циља”, послали су га као „аташеа за културну пропаганду у посланству Краљевине Срба, Хрвата и Словенаца" у Берлин да би овде попунио место које је пре њега заузимао Станислав Винавер. Црњански је у Берлину остао годину дана, до лета 1929. године када је био принуђен да се врати у Београд, пошто су у његовој домовини избили политички немири. У Београду је поново почео да ради као професор гимназије и журналиста, али ускоро је тај посао прекинуо. Планирао је да се врати у Берлин са намером да студира, али то из финансијских разлога није могао да реализује. Тек крајем 1935. године поново путује у Немачку.

О својим доживљајима током боравка у Немачкој, Црњански пише у Кюизи о Немачкој, путописној збирци која је изашла 1931. године. Ирис Берлина, не само најобимнији је већ и средишни део ове књиге.

Овај путопис је вишеструко значајан. Прво - он је релевантан са чисто књижевног становишта. Друго - он има документарну вредност и представља објективан извор за друштвени и политички развој вајмарске Немачке након Првог светског рата, у време њеног прелаза из кризе двадесетих година ка критичним и судбоносним тридесетим годинама. Tреће - то је интересантан и импресиван извор за студију слике великог српског писца о Немачкој и Немцима.

Као књижевни текст, Ирис Берлина је израз трагања за новом стварношћу у књижевном стваралаштву и трансформације експресионисти- 
чког проседеа у документаран и аналитичан поступак. Тај развој се може пратити и у самим путописима Црњанског. Његови рани путописи попут Писама из Париза или Љубави у Тоскани, представљају субјективни доживљај реалног света и једну врсту поетске прозе која стилски подсећа на пишчев роман Дневник о Чарнојевићу - о томе, између осталих, пише Марко Недић (Недић 1972, 282). У каснијим путописима, којима између осталих припада Минхен, Писма из Париза и Ирис Берлина, преовлађује реалистички приступ стварности. Субјективне књижевне теме као љубав, тема завичаја или уметнички доживљај, овде остају у позадини, док је у центру нарације стварност коју уметник запажа и аналитички описује. Адресати ових путописа очигледно нису ексклузивни читаоци ранијих времена него један шири круг читалаца. Поред све своје конкретности и фактографије, путопис Црњанског, међутим, има и своју индивидуалну књижевну боју и поетичност.

У односу на српску путописну књижевну традицију, Црњански је особен и оригиналан јер у свим својим путописима даје субјективну визију и пројекцију личног доживљаја стварности (Недић 1972, 282). На тај начин „непесничка” прозна форма са реалним, нефикционалним контекстом постаје истовремено проза са литерарним предтекстом и са индивидуализованим емоционалним доживљајем. Имамо пред собом синтезу субјективне уметничке визије и објективне слике света. Осим тога, у путопис улази и књижевно и лично животно искуство песника. То важи и за Ирис Берлина.

Ирис Берлина - наслов описа Берлина за време Вајмарске републике, је програмски. Ирис односно дуга, тачније боје дуге, имају функцију лајтмотива. Разноликост града Берлина у двадесетим годинама Црњански тумачи посредством боја, преносећи боје дуге на животне појаве у метрополи. Симболична употреба боја је типично средство приказивања Црњанског; у овом контексту мислимо, на пример, и на његову суматраистичку симболику беле, црвене и плаве боје у Дневнику о Чарнојевићу. У Ирису Берлина боје, међутим, имају друго значење. О томе ћемо касније.

Црњански у Ирису Берлина опширно описује динамичне и муњевите промене у Берлину у време Вајмарске републике, у периоду између послератног хаоса и фашистичке експлозије, која је настала неколико година касније. У то време град је имао више од четири милиона становника и постепено се развијао постајући својеврсни Њујорк Европе, односно „симфонија велеграда” како га је 1927. године описао познати режисер Валтер Рутман у свом документарном филму. Црњански опажа све сегменте тог града; описује његову природну околину, архитектуру и становништво: мушкарце и жене различитих социјалних слојева, њихов 
изглед, њихов нормативни систем мишљења и понашања као и њихово социјално и економско стање; политички и културни живот града као и војску и полицију који су у служби одржавања реда и поретка. Као посматрач Црњански је објективан и аналитичан, а његови судови обилују често индивидуалним проценама. Пишчево виђење Берлина представља несумњиво валидан историјски извор за упознавање друштвених структура и политичких процеса за време Вајмарске републике - на то указује и историчар Милан Ристовић (Ристовић 1996, 259-267). У свом опису Црњански чак и прогнозира даљи политички развој Немачке, односно њену десничарску радикализацију, па, између осталог, закључује: „Удар са десна може доћи!” (Ирис Берлина, 257²).

Најважнији формални и садржајни принцип казивања у Ирису Берлина је упоређивање супротних, често пута међусобно противуречних слика и ставова: Црњански у свом опису супротставља предрасуде и представе о Немачкој стварности коју он запажа; прилике из ранијих времена и садашњости, своје утиске о граду током дана са утисцима које он изазива ноћу - и све то чини користећи контрастне боје, безбојност или шаренило.

На почетку свог путописа, суочен са шаренилом боја и пулсирајућим ритмом Берлина, Црњански жели да промени ону слику о Немачкој која је дочарава сивим и тамним бојама, а Немца види као безбојан лик. Више пута наглашава да је та представа погрешна, да немачке појаве и ствари не само да нису безбојне, већ су, напротив, густо шаренило: „црвено, жуто, плаво, провидно и упаљено зелено" (Ирис Берлина 203). Описује слику која има:

„велике површине оштрих боја, огромне, префарбане квадрате и паралелограме и, у њима, гигантске конструкције гвожђа, у непрекидној промени" (Ирис Берлина, 202).

Црњански настоји да модерним језиком урбане импресивности дочара богатство боја савременог живота на улицама Берлина, да пружи сугестивну слику градског асфалта и камена, семафора и скретница, рекламних натписа, фарова од аутомобила, возова и небеских фатаморгана над градом као и боје његових шума и језера. У богатству боја Црњански види нову романтику индустријског доба. Непрекидно описујући то шаренило, Црњански као да је опседнут динамиком града. У исто време се, међутим, осећа несигурно и угрожено. Застрашено констатује:

\footnotetext{
1 За цитате је коришћено издање 1966. г., види у библиографији.
} 
„Земља која има најмоћнију индустрију боја и једно старо, недовољно познато, ванредно сликарство, није сива, ни глупо безбојна. Земља најлепших кестенова, језиво зелених пропланака, сад, све више надзидана у бетон, гвожђе, у стакло, светли се од боје и дању и ноћу." (Ирис Берлина, 204)

Песник жудно тражи изгубљену тишину природе:

„урећи аутом, брзином без шума, или на точковима што пљуште, износи се тело у природу, али то више нема, за душу, последице једног дугог живота са пољима и брдима, стадима и мравима, већ само утисак нечег изгубљеног и уметног, меланхолично буколичног". (Ирис Берлина, 205)

Упоређујући Немачку вајмарског доба са Немачком из прошлости, Црњански констатује губитак, нестајање свега што је некад било познато и привлачно и о чему пише приликом посете Вајмару и Јени следеће:

„некад учили великошколци из Србије и где ритам живота постаје спорији и тиши...” - и где су „дане и вечери, у узаним улицама, иза старе градске цркве, где је становао Хердер, по сенкама и спокојством старих кровова" (Црњански, Путописи I, 1995, 324 и сл.).

У Ирису Берлина поново се подсећа на минула времена:

„Да виде ону стару, давно прошлу Немачку, што је живела око цркава, у саосећању нагона пролећних и јесењих, у бригама око клијања и жетве, рађања и смрти. Немачку мирну и доцније, романтичну и либералну, једном речју, срећну, пре него што је поведоше они, Пруси." (Ирис Берлина, 256)

Што више Црњански посматра живот и људе у немачкој метрополи, тим више ишчезава ексктатична слика нове романтике метрополе, ишчезавају жарке боје првих утисака о граду, а из његове позадине на сцену ступају сива боја, сива маса становника, сиве статистике о индустријском и економском стању, о моралном паду и хаотичном стању града. Паралелно са тим мења се начин казивања. Додир уметника са чудовиштем модерне, американизоване цивилизације, присиљава га да користи документаран публицистички стил, стил нове стварности, гомилајући факта и статистичку грађу.

Црњански заузима критички став према неоромантичарским вредностима метрополе и модерне урбане цивилизације. Хипермодерни свет технике, технологије, економије и политике, који је на почетку прихватао 
као симбол једне нове романтике, на крају му постаје одбојан. Осећа се угроженим неуморном виталношћу Немаца која по његовом мишљењу може и да добије опасне црте. Жели да побегне у природу, у зелене шуме града:

„Зу хиперболан живот, Берлин је жељан бруталног додира са прашумом, топлим и великим Срцем Земље."

Окреће се према ономе што му је ближе: уметничким старинама, културним знамењима, природи, ноћном животу са вештачком светлошћу. Увече, „када су душе постале лакше, мекше” и „када се ништа од 'Берлина на дану' скоро не види”, не осећа се „модеран, материјалан, машински смисао" дана, атмосфера града му се чини много пријатнија.

Црњански критички запажа да се економски и политички центар Немачке у тој мери американизовао да се потпуно одвојио од конзервативне и мирне провинције. Хипермодеран свет технике, „ново лудило индустријске и механичке виталности људи”, који су само сконцентрисани на свој посао и стално жваћу жвакаћу гуму - све му је то неприродно и покварено; пише:

„Замара и отуђује, дакле, после дужег времена, та гломазна варош, у непрекидном понављању немачких јада и неправди које јој се наносе." (Ирис Берлина, 260).

Црњански испољава јаку дистанцу према том свету са којим никако не може да се идентификује. Пишући о Ирису Берлина поједини истраживачи су Црњанског оптуживали да је германофоб (на пример, Дурман 1931, 254-256; Машек 2004, 121). Чини ми се да они не узимају у обзир, да се став Црњанског према приликама, људима и стварима које запажа у Берлину, често мења: час их описује позитивно, час критички, са дистанцом и негативно. Скакућући и у приповедању, о истим стварима пише различито и непрестано мења своје становиште. Текст нема хомогену структуру и каузалну хронологију, него представља један мање-више случајан низ импресија.

Како види Црњански Немце? Најјачи утисак на њега, као и на друге српске путнике, чини марљивост Немаца. „Тамо нема никога ко не ради”, констатује Црњански (Ирис Берлина 216). Сматра да је ова марљивост, ипак, претерана и неприрода, чак и штетна:

„Основа берлинског живота је тежак рад. Колико се пута учини бесмислен! У лажном сјају неке Слободе, што обухвата као челична решетка, без хуманости, сем сажаљења што се јавља као аксидан, 
пролазан и лутријски, тај живот раднички, американизиран, са непрекидним и узалудним побољшањима, бедан је, нарочито по томе што се у њега једнако враћају, у механизиране форме, сентиментални садржаји, давно демодирани." (Ирис Берлина, 255)

Пада му у очи да су Немци увек тачни: „Ко задоцни губи право на верност”, пише Црњански (Ирис Берлина, 217). Дисциплина Немаца, међутим, њега уопште не одушевљава:

„Први мој осећај за њих: муче се, муче се и напрежу. Устрељени су стрелом жудње да подижу брда, да преносе, ма шта, али да зидају. Нису зли; ударени су громом вавилонским; не виде да је све пролазно; заборављају своју душу, као у немачким причама, ђаво им односи сенку; ископали су Троју, али никада да стану, да стану и да се загледају онамо, где је „горе” и „доле” исто, где је мир и лепота коју је певао Мезомед." (Ирис Берлина, 223)

Црњански сматра да су Немци, као и Руси, необично витални. Пише: „Седамдесет милиона Немаца и сви слични. Вечни и просто, већ зато, брутално витални" (Ирис Берлина 242). Били би симпатичнији, сматра Црњански, да су се свету показали са својим слабостима. Црњански се диви, али се у исто време и боји виталности и некритичног веровања Немца у свемоћ технике.

„Његов ће елан бити и даље достојан дивљења, али ће све више бити грозничав од инјекције американског капитала, индустријског империјализма - велике илузије као што беше и војнички - од све те психозе грандоманије, у којој има опет, тако брзо, толико вилхелминског." (Ирис Берлина, 238)

У оквиру једног свесловенског пројекта, Црњански и овде конструише један извор праве виталности. Слично другим српским авангардним писцима, он претвара примитивно и заостало у виталну и моралну надмоћ. По његовом мишљењу будући потенцијал и нова сила уморне Европе су Словени. Већ у његовим првим путописима о Немачкој, Француској и Италији који су се 1921. и 1922. године појавили у књижевном часопису „Нова Европа” осећа се пишчева потреба да разликује сопствено од туђег (Црњански, Писма из Париза, 9-47, 501-508). Са намером да се дефинише сопствен националан колектив из перспективе јужнословенског колектива, овде се налазе прве примедбе о карактеру других „нација” и о Европи. У Писму из Париза име града Париза сигнализира „Европу” односно опасност у дихотомији „ми” с једне и „Европа” с дру- 
ге стране (Ковач 1988, 117). У Ирису Берлина Црњански понавља став о сопственом. Пише:

„Ја знам само да, ако баш треба неког волети, онда ћу волети оне који су највише патили. А то смо, засад, изгледа, ми”. (Путописи I, 24)

И у Ирису Берлина даје предност архаичности Источне и Југоисточне Европе кад пише:

„У првим моментима берлинским, причињавају се, као фатаморгане дивне, земље сунчане, лаке, латинске, са Паризом, Фиоренцом и Римом; незаборавне чак и оне друге, источно: Пољска, Русија, Румунија, „заостали” део Европе, где још има коња, колиба, топлих јесени у којима живе сањала, пролећа, мирисних од отопљеног снега, која удишу сладострасници, и бескрајних ноћи, за пастире.” (Ирис Берлина, 221)

Све у свему, Црњански није одушевљен Берлином ни његовим становницима. Њихов менталитет му је очигледно туђ:

„Оно што сам ја од њих тражио, чинило им се: као да неко тражи од пруске пешадије да се претвори у балетску групу, а оно што су ми они нудили, чинило ми се: као да је неко тражио да оставим сне, небеса и љубави, за један живот у гару, зноју и жвакању." (Ирис Берлина, 261)

У неким аспектима, ипак, показује разумевање, чак и симпатију за прилике у Берлину. Признаје да је тражећи да тај град боље упозна, лутао њиме и ускоро је имао осећај сажаљења и другарства за људе, пише:

„jер сви су се мучили и нису били друго, до ми сами, у другим животима... Друкчији него Словени, ипак су ти људи били као и други. Бескрајна сличност људских гестова и рефлекса, на целом свету, па и ту." (Ирис Берлина, 221)

Постепено аутор открива и позитивне појаве на улицама Берлина:

„Па ипак, та американизирана, чиста и рационална (безбројне одредбе, егзерцирна правила Општине), берлинска улица, при првом погледу има у себи толико уздржљивости, озбиљности, па и племенитости. Пред женом са малим дететом, пред болесником, трамвајџија и најгора гурала натера на ред. Прво место до врата 
припада инвалидима, општинским решењем и наредбом управе Саобраћајног друштва. Ма каква се незгода десила, та маса, што збиља нема времена, сама се нуди да сведочи, да помогне и праведна је, тврдоглаво бранећи истину. (Скоро да се не верује да су то они исто мозгови из 1914.)” („Ирис Берлина”, 223)

Посматрајући људе дуже времена, признаје да менталитет Пруса, иако му није близак, ипак, има и својих врлина:

„Начин пруски је хладан, без наполитанског шарма, али и без оне брзе и сувишне интимности јужњака, што, са љубазношћу, преноси и своје буве." (Ирис Берлина, 222)

Црњански сматра:

„немачки” дијалог је јасан, начин Немца врло одмерен, охол, али никад наметљив, никада чулан, кад је у питању синтеза”. (Ирис Берлина, 244)

Пруски полицајац и возачи аутобуса посебно привлаче пажњу Црњанског. О полицајцу пише:

„Шармантан је, по наређењу, кад заустави цео саобраћај да би прешла нека дечја колица." (Ирис Берлина, 225)

Мушкарце Црњански махом сматра неатрактивним. О њима пише следеће:

„Журећи за послом, мушки су сви слични, без карактеристичног у масци, сем фризуре... Апсолутно нееротични сценски, они не прате, никад жене погледима, нити им досађују. У том погледу, Немачка, далеко је, на улици и у саобраћају, над обичајима европским. Но у исти мах, ти иначе крупни, пословни људи, имају непријатне очи и покрете воштаних фигура, често под цилиндром (иду пешке и трамвајем, чак и у фраку). Жучни и тврдоглави, један према другом, до зла бога." (Ирис Берлина, 217)

Признаје, међутим, да су млади Немци често пута необично лепи:

„Лепих германских глава, ванредних тела, што крај кривоногих и здепастих других раса, упалих груди, изгледају прави германски богови. Као и према својим старијим генерацијама, пивопијама, што се чине као оденута бурад, са главама као тикве." (Ирис Берли$\mathrm{Ha}, 280)$ 
И Немице, у ствари, не одговарају укусу Црњанског. О њима каже следеће:

„Жене, очију боје бршљана и ванредног плаветнила, до љубичастог, имају, кад нису у тренчкоту, чудне аранжмане гардеробе, а као главну црту телесног састава: готичку слабост груди и инферналну снагу трупа." (Ирис Берлина, 217)

Оне су по његовом мишљењу као и мушкарци недовољно осећајне, пише:

„Сентименталности код њих нема, као, уосталом, нигде и ни у чему више, у Немачкој”. (Ирис Берлина, 217)

Другачије, са великим поштовањем, односе се једино према старим женама када им, на пример, уступају своје место. Црњански запажа, да Немице никад ружну или ласцивну реч не би изрекле, и то је оно што као позитивно оцењује код њих:

„имају у себи, још увек, чувену чар, das deutsche Mädchen; die deutsche Frau, хладнију можда него пре. Јасне и мирне, на место сентименталности и глумачких испада (Немице не воле тип заводника), уносе сад у своје (ретке) љубави и своја (честа) искрена пријатељства ћутљиву неку кроткост, што је у ствари увиђавност да дубоког, чулног, истинског заноса једва сад и има." (Ирис Берлина, 280)

Посебну пажњу поклања променама друштвеног положаја немачких жена које су се после рата толико еманциповале да су стекле чак водећу улогу у јавном животу: у парламенту, у општинској управи, на универзитетима, у медијима и у привреди. Са дивљењем примећује способност женских лекара и спремност протестантске цркве да прима жене као свештенике. Забележио је да је 1920. године у Немачкој запослено 9,5 милиона жена, више него у Америци или у Енглеској у исто време. Црњански указује, међутим, и негативне црте тог процеса:

„Жена после рата, економски се ослобађа. Не мора више да служи, ни да се претвара. Брак пада... Данас се девојка од седамнаест подаје, јер је то опште." (Ирис Берлина, 278)

Црњански пропагира традиционални однос полова и критички се односи према паду традиционалних моралних критерија. Берлин види као Вавилон перверзија, хомосексуалности и „полусвета, нафраканих бабетина и макроа". 
Позиција Црњанског према Немачкој и Немцима се знатно мења у тридесетим годинама када други пут борави у Берлину од краја 1935. до почетка 1938. године. Овог пута запажа прилике и људе у Немачкој као чиновник Министарства спољних послова Краљевине Југославије. Под псеудонимом „М. Путник”, запослен у Централном пресбироу, редовно пише званичне извештаје о дневним политичким догађајима, репортерске записе и коментаре, посебно о ширењу националсоцијалистичког покрета, за београдски лист „Време”.

За време свог другог боравка у Немачкој, Црњански се ближе упознао са свим водећим националсоцијалистичким политичарима и генералима. Рудолфа Хеса, заменика Хитлера, на пример, представља на следећи начин:

„Он је најлепши и најмлађи међу њима. Његово лице је африканске лепоте и има сасвим чудне очи. Он је сасвим тих и изгубљен у своје мисли, али кад бих био Немац, ја бих у њега, имао у текућим тренуцима, највише хуманог поверења.” (Аврамовић 1990, 52)

Министра за спољне послове, Барона фон Нојрата сматра мајстором дипломатије који је искрен, оптимистичан, мирољубив и опако паметан (Аврамовић 1990, 126). Високо оцењује и Генерала Рибентропа, личност високе културе и племенитог лика (Аврамовић 1990, 128).

Црњански је и познавао Хитлера самог. Године 1973, 13. септембра, пише о томе да је Хитлер у тврђву Нирнберг од 250 новинара који су присуствовали на националсоцијалистичком конгресу примио осам страних новинара, међу којима и њега самог. Он је уживао симпатију Хитлера:

„Пошто сам ја био поред њега, а знао је да сам југословенски новинар, он је обгрливши ме руком преко рамена, рекао: - У Југославији је питање мањина врло добро решено." (Аврамовић 1990, 17)

Даље пише:

„Хитлер ми се три пута обраћао и пред свима новинарима светске штампе ... најлепше ми се захваљивао за објективно приказивање ситуације у Немачкој." (Аврамовић 1990, 17)

Очигледно се Црњански осећао поласкан комплиментима Фирера и других великана Трећег Рајха. Поред тога није имао довољно политичких знања да правилно процењује њихове циљеве, јер у својим извештајима махом позитивно представља ситуацију у Немачкој и занемарује упозо- 
равајуће гласове из иностранства у односу на националсоцијалистички покрет. Негативан став енглеске штампе према збивањима у Немачкој сматра обманом и самообманом. Тако 19. новембра 1937. године између осталог записује:

„Оно што се пре писало и говорило о нацизму и нацистима у Енглеској, била је карикатура." (Аврамовић 1990, 115)

У његовој репортажи под насловом „Хитлер као централист” описује успехе Хитлера у стварању једне централистичке Немачке. Хитлер има само једну визију, пише Црњански, и то је „Немачка без унутрашњих граница”. Сигурно је по његовом мишљењу да Хитлер неће стати на по пута и да није далеко време када ће Немачка на карти Европе бити само „једно велико јединствено срце које моћно куца и чији су сви делови једне боје, једне крви, једне осетљивости и једног звука" (Аврамовић 1990, 94).

Више пута примећује да Немачка колико год је постала велика, жели мир (Аврамовић 1990, 31, 49, 123). Мир је, пише Црњански 10. фебруара 1938. године, заслуга Хитлера и људи из његове најближе околине; дословно:

„Није идеал нациста један рат, него је њихов идеал једна нова Немачка и један нов немачки народ." (Аврамовић 1990, 124)

Хитлера описују као човека који има много такта (Аврамовић 1990, 78) али и хумора (исто, 94) и као човека из народа са сентименталношћу који не заборавља своје порекло (исто, 86).

Анализирајући те текстове, Зоран Аврамовић (1990) правилно констатује да Црњански није био теоријски политички ум и да се нашао у једној држави са идеологијом која је у то време представљала нову појаву у свету, са чијим трагичним последицама ће се свет тек суочити. Ако у тим извештајима Црњански позитивно пише о друштвеним и политичким променама у Трећем Рајху, треба свакако узети у обзир да то ради као чиновник Краљевине Југославије, земље, која је тада имала пријатељске односе са Трећим Рајхом. „Није се могла очекивати од њега јавна артикулација критичног става" - пише сасвим оправдано Аврамовић. Истиче да Црњански у својим коментарима не скрива природу националсоцијалистичке идеологије и начин њеног стварања, да указује на кључне елементе тог покрета (Аврамовић 1990, 9) и да не може бити говора о томе да је Црњански био присталица фашизма. При томе се социолог Аврамовић највише ослања на једно место у извештају Црњанског под насловом „Ко ће победити? Пије XI или националсоцијализам?”: 
„Ипак ова борба људи за слободу мишљења, ма колико била парадоксална, служи на част Немцима, народу који није само, како се то по Европи пише, народ полицајаца и војника, него и народ мислилаца и песника". (Аврамовић 1990, 70)

Без сумње, овај цитат подржава тезу Аврамовића. Потврду за овај став налазимо и у мањем путопису Црњанског из 1929. године под насловом „Осмех синагоге на хришћанској цркви”. То је краћи лирски опис скулптуре на спољним зидовима бамбершког храма: Синагоге, младе Јеврејке у камену, са завезаним очима која побеђена и клонуло стоји пред другом младом женом у камену, која симболизује победоносну хришћанску цркву. На крају је следећи опис, који пружа не само посебан естетски доживљај већ и особен доживљај другог и другачијег:

„Тајанствена и висока, дивна и без круне и плашта, она стоји ту, од камена, на хришћанској цркви. Очи су јој везане, али осмех јој је изложен ветровима и зрацима пролећа и колико она друга гледа око себе, ова гледа у себе и смеши се, надмудрена у препирци. Зна да су сестре, и спокојна је, у својој лепоти." (Аврамовић 1990, 141)

Због службене функције коју је Црњански обављао, тешко је правилно проценити његове извештаје о Хитлеровој Немачкој. Коначан суд је о овом питању тешко дати. Треба још више истражити ту делатност Црњанског и прикупити податке код пишчевих савременика. Ови текстови у сваком случају представљају важан извор за истраживање развоја немачког националсоцијалистичког покрета до 1938. године и заслужују пажње и у Немачкој.

Кључне речи: Милош Црњански, „Ирис Берлина”, путопис, Берлин, Немци, Немачка, Зоран Аврамовић.

БИБЛИОГРАФИЈА

Аврамовић, Зоран (ур.): Црњански о националсоцијализму. Београд, 1990.

Вучковић, Радован: Путописи Станислава Винавера и Милоша Црњанског о Немачкој. Кюига о путопису. Зборник радова. ур. Слободанка Пековић. Београд, 2001, 283-295. 
Голубовић, Видосава: „Путописна репортажа Милоша Црњанског”. Кюига о nутопису. Зборник радова. ур. Слободанка Пековић. Београд 2001, 189-199.

Дурман, Милан: М. Црњански, „Књига о Немачкој”. Кюижевник, Загреб 1931, IV, 7, 254-256.

Ковач, Звонко: Поетика Милоша Цръанског. Ријека 1988.

Константиновић, Зоран: Немачка у српским путописима. Кюига о путопису. Зборник радова. ур. Слободанка Пековић. Београд, 2001, 275-281.

Mašek, Miro: Nation und Narration im literarischen Werk Miloš Crnjanskis. Frankfurt am Main, 2004.

Недић, Марко: Путописна проза Милоша Црњанског. Кғижевно дело Милоша Црнанског. Зборник радова, ур. Предраг Палавестра. Београд, 1972.

Поповић, Радован: Живот Милоша Црюанског. Београд, 1980.

Ристовић Милан: Ирис Берлина и схватање историјског времена. Милош Црюански. Историјско-естетички приступ кюижевном делу. 3борник радова, ур. Милосав Шутић, Београд, 1996.

Црњански, Милош: Путописи. Сабрана дела. Београд, 1966.

Црњански, Милош: Путописи I. („Писма из Париза”, „Љубав у Тоскани”, „Наша небеса”. „Књига о Немачкој”. „У земљи тореадора и сунца”). Београд 1996 (Дела Милоша Црњанског т. 8.)

Црњански, Милош: Нова Европа. Предговор, избор и коментари Радивој Цветићанин. Београд, 1991.

Црњански, Милош: Политички списи. Приредио и предговор написао: Зоран Аврамовић. Београд,1989.

\section{Gabriella Schubert}

\section{DAS DEITSCHLAND - BILD BEI MILOS CRNJANSKI}

\section{Zusammenfassung}

Der bedeutende serbische Schriftsteller Miloš Crnjanski besaß vielfältige Kenntrisse Deutschlands - aus der Lektüre deutscher Literatur ebenso wie aus persönlicher Anschauung. Mehrfach, zeuerst 1928-29, und danach vom Dezember 1935 bis zum März 1938, hielt er sich in Deutschland auf.

Seine Erlebnisse in Deutschland während seines ersten Aufenthaltes schildert Crnjanski in einer Sammlung von Reiseberichten unter dem Titel Knjiga 
o Nemačkoj [Buch über Deutschland], das 1931 erschien. Im Mittelpunkt dieser Sammlung steht sein Bericht unter dem Titel Iris Berlina [Berliner Regenbogen], der zugleich auch der längste ist.

Diese Reisebeschreibung ist unter verschiedenen Aspekten bedeutsam. Erstens handelt es sich um einen literarischen Text mit vielen interessanten Aspekten. Zweitens ist sie eine wertvolle Quelle in Bezug auf die gesellschaftliche und politische Entwicklung Deutschlands nach dem Ersten Weltkrieg, in Weimarer Zeit, einer Zeit des Übergangs von der Krise der zwanziger Jahre zu den kritischen und schicksalhaften dreißiger Jahren. Drittens ist sie auch unter imagologischen Gesichtspunkten aufschlussreich; sie ist eine interessante und eindrucksvolle Textgrundlage zum Deutschland-Bild des bedeutenden serbischen Schriftstellers.

Iris Berlina dies ist der Titel der Beschreibung der Stadt Berlin in den Jahren der Weimarer Reublik. Iris - der Regenborgen bzw. die Regenbogenfarben - haben leitmotivische Funktion. Die Vielfältigkeit der Stadt Berlin der zwanziger Jahre warden mit Hilfe von Farben sinnfällig gemacht wird. Eingehend beschreibt Crnjanski in Iris Berlina die Dynamik und die rasanten Veränderungen Berlins in der Weimarer Zei, in einer Übergangsphase zwichen dem auf den Ersten Weltkrieg folgenden politischen und wirtschaftlichen Tief und der 1933 beginnenden Radikalisierung.

Deutlich wird in dieser Beschreibung sein Empfinden der Fremdheit und Distanziertheit gegenüber der beschriebenen Welt, mit der er sich nicht identifizieren kann. Verschiedentlich wurde Crnjanski in seinem „Buch über Deutschland" Germanophobie unterstellt.

Wie nun beschreibt Crnjanski die Deutschen? Am meisten beeindruckt ihn wie auch andere serbische Reisende der Arbeitseifer der Deutschen. Diesen Arbeitseifer hält er jedoch für übersteigert und unnatürlich, ja schädlich. Auch die bedingungslose Pünktlichkeit der Einwohner fällt ihm auf. Die Menschen nimmt er unterschiedlich wahr, und er beurteilt sie uneinheitlich - mal als steif, unauffällig und ohne Ausstrahlungskraft, mal als freundlich und ansehnlich Andererseits bewundert er junge Männer

Auch das Äußere der deutschen Frau ist nicht nach dem Geschmack des Erzählers

Das Eigene und das Fremde kann im Kontakt Crnjanskis mit seinen Berliner Gesprächspartnern nicht harmonisiert werdenNicht ohne Mitgefühl, beschreibt Crnjanski auch die soziale Not, derer er in Berlin Zeuge wird.

Die anfängliche Abneigung gegenüber dieser Stadt und seinen Einwohnern wird jedoch nach tieferer Einsicht wieder revidiert. Er bewundert die Höflichkeit und Rücksichtnahme der MenschenDie preußische Gemütsart habe durchaus Vorteile:

Eine eindeutig andere Position nimmt er wie bekannt in den dreißiger Jahren ein, als er zur Lösung der serbischen nationalen Frage die Etablierung eines starken, zentralistischen serbischen Staates befürwortet und die Vorbilder dafür namentlich im Nationalsozialismus Deutschlands sucht. 
Crnjanski widmet sich auch den negativen Entwicklungen der Metropole Berlin: der Kriminalität, Prostitution. als „Babylon von Perversitäten”.

Insgesamt zeigt dieses Bild viele verschiedene Facetten. 